\title{
The Influence of Corporate Governance Structures on Compliance with Mandatory IFRSs Disclosure Requirements in the Jordanian Context
}

\author{
Marwa Hassaan ${ }^{\mathrm{a}}$, \\ ${ }^{a}$ Mansoura Faculty of Commerce, Mansoura, Egypt ${ }^{b}$
}

\begin{abstract}
This study examines the impact of corporate governance structures on the levels of compliance with mandatory IFRSs disclosure requirements by companies listed on the Amman Stock Exchange (ASE) as a leading Arab stock exchange. Using a disclosure index derived from mandatory IFRSs disclosure requirements for the fiscal year 2007, this study measures the levels of compliance by a sample of 75 non-financial companies listed on the ASE. This study extends the financial reporting literature and the emerging markets disclosure literature by being one of the first to investigate the influence of corporate governance requirements for best practices on the levels of compliance with mandatory IFRSs disclosure requirements by companies listed on the ASE. Results provide evidence of the lack of influence of corporate governance best practices on the levels of compliance with mandatory IFRSs disclosure requirements as it is not yet part of the cultural values within the Jordanian context. These findings are consistent with the notions of the theoretical foundation employed in this study.
\end{abstract}

Keywords: IFRSs; Jordan; ASE; Board Leadership; Board independence; Board size; Ownership Structure

\section{(C) 2013 Published by SSBFNET}

\section{Introduction}

The development of corporate governance is a global phenomenon, influenced by legal, cultural, ownership, and other structural differences (Mallin, 2009), but as yet there is no widely accepted paradigm or theoretical foundation in its respect (Tricker, 2009). Corporate governance is concerned with the system of directing and controlling companies, and it is the responsibility of BOD (Cadbury Committee Report, 1992). It is a fundamental element in improving economic efficiency and growth as well as enhancing investor confidence (OECD, 2004). The BOD actions are subject to laws, regulations and shareholders in general meeting, and the role of shareholders in governance is to appoint the directors and auditors and to make sure that the governance structure is appropriate (Cadbury Committee Report, 1992). For transitional economies, good corporate governance practice may be essential to guarantee the success of their reform programmes and to create a healthy investment climate. However, the corporate governance codes for best practice were initiated in developed countries and only recently introduced in developing ones. Hence, its contribution towards enhancing capital market performance in such countries is subject to the extent to which the conditions for robust governance practice are consistent with the existing values, past experiences and the needs of all parties involved in the financial reporting process. It is expected, therefore, to be some time before the impact of applying corporate governance can be measured in developing contexts as this needs to develop, and favourable attitudes and belief must be formed as well as efforts being made to develop the human resource capabilities to apply corporate governance requirements for best practice.

Unlike the majority of Asian Arab countries, the Hashemite Kingdom of Jordan is considered as a lower-middleincome economy with limited natural resources, and for years its economy was based on financial assistance from the Gulf countries. Hence, there is a need to develop their capital market to be the vehicle for economic development. Concerning the adoption of IFRSs in Jordan, this was stimulated by the open trade agreements with foreign partners in

\footnotetext{
${ }^{a}$ Corresponding author.
} 
the EU and USA as well as pressures from the WB and other international lending institutions which necessitated the development of the Jordanian accounting system to enhance the credibility of financial statements (Al-Akra et al., 2009). Before 1998 the Amman Financial Market (AFM) founded in 1978 was seen as an unregulated financial market as listed companies were not mandated to adopt a specific set of disclosure requirements (Al-Akra et al., 2009). Consequently, one of the main contributions of what is referred to as the Economic Reform Programme commenced in Jordan in the 1990s, is the massive development and restructuring of Jordan's Financial Market in order to globalise its activities. The restructuring of the AFM resulted in the development of three new institutions, namely: the Amman Stock Exchange (ASE), Jordan Securities Commission (JSC), and Securities Depository Centre (SDC) (Al-Akra et al., 2009; Al-Omari, 2010). Additionally, the reform involved the establishment of the Jordanian Corporate Governance Association to promote the implementation of effective corporate governance practices throughout Jordan. In Jordan, the Companies Law of 1997 mainly covers some corporate governance rules that relate to the auditor. On the other hand, the Securities Exchange Law of 2002 helps in activating the rules of governance by defining market regulations, the issuance of shares or bonds and trade procedures. It also states the responsibilities of issuers of securities, brokers and auditors, and the requirements for listing in the stock exchange, protection procedures for minority rights and the requirements for disclosing important information. Furthermore to preserve transparency, the law prohibits related party transactions, promoting rumours, misleading investors and disclosing any matters that may adversely affect the capital market (Shanikat \& Abbadi, 2011: 96).

A number of studies have been conducted in the last decade for the purpose of investigating the relationship between corporate governance and corporate disclosure practices in different countries (e.g., Chen \& Jaggi, 2000; Haniffa \& Cooke, 2002; Gul \& Leung, 2004; Abdelsalam \& Street, 2007; Ezat \& El-Masry, 2008; Felo, 2009; Al-Akra et al., 2010a,b; Samaha \& Dahawy, 2010; 2011; Abed et al., 2011; Alanezi \& Albuloushi, 2011). This study extends the study of Al-Akra et al. (2010a) in Jordan by using more recent data and investigating the impact of board leadership and management ownership ratio on the levels of compliance with IFRSs. As disclosure lies at the core of all corporate governance statutes and codes, investigating the association between corporate governance structures and the levels of compliance with IFRSs disclosure requirements is expected to enrich financial disclosure as well as corporate governance literature. This paper addresses two research questions: What is the level of compliance with mandatory IFRSs disclosure requirements by companies listed on the ASE? How could differences in the levels of compliance with the IFRSs be explained by corporate governance structures? In order to answer the above mentioned research questions, the remaining part of the paper is organised as follows: A literature review is provided in Section 2. Section 3 develops and formulates research hypotheses. Section 4 describes sample selection, data collection, and research methods. Results and analysis are presented in Section 5. Finally, Section 6 concludes.

\section{Literature Review and Formulation of Research Hypothesis}

Transparency, fairness and accountability are the core values of corporate governance. Stemming from the desire to enhance access to more capital that is necessary to achieve economic development and globalise national economies, corporate governance practices have been brought in the spotlight in developing countries. In this regard many researchers highlight the influence of corporate board characteristics and ownership structure (e.g., Eng \& Mak, 2003, Ghazali \& Weetman, 2006; Ezat \& El-Masry, 2008; Al-Akra et al., 2010a,b) on disclosure practices of companies listed on developing stock exchanges. However, this study suggests that as corporate governance was initiated in developed countries and as it is newly introduced in developing countries, its contribution to enhancing capital markets' performance is subject to the extent to which the requirements for good corporate governance practices are consistent with the existing values, past experiences and the needs of all parties involved in the financial reporting process. Otherwise, it is expected to take some time until the impact of corporate governance can be measured. This is because it needs developing an understanding, forming a favourable attitude and belief and developing the skills required to apply corporate governance best practice.

\section{Development of Hypotheses}

This section illustrates the development of the research hypotheses formulated to examine the influence of board of directors (BOD) characteristics (BOD independence, BOD leadership and BOD size) and ownership structure (government ownership ratio, management ownership ratio, private ownership ratio and public ownership ratio) on the levels of compliance with IFRSs disclosure requirements in the Jordanian context. Additionally, the section indicates those variables to be used as control variables (company size, profitability, gearing, liquidity, type of business activity, 
and type of audit firm) as identified in previous research as being associated with financial disclosure practices and compliance. In each case expectation is stated based on prior literature.

\subsection{Board Independence}

Board independence is an outcome of the number of independent directors in the board of directors (BOD). Corporate governance reform in Jordan supports board independence (Al-Akra et al., 2010a,b).

The findings of the only study that investigates the association between board independence and mandatory disclosure practices in Jordan (Al-Akra et al., 2010a), do not support the existence of any significant association. Consequently, this raises the need for further investigation. On the other hand, the findings of prior research that examined the association between board independence and financial disclosure are mixed which makes it difficult to predict the relationship between board independence and levels of compliance with the IFRSs. Some researchers report a positive relationship (e.g., Arcay \& Vazquez, 2005; Cheng \& Courtenay, 2006; Abdelsalam \& Street, 2007; Abdelsalam \& Elmasry, 2008; Ezat \& Elmasry, 2008; Felo, 2009). In contrast, some researchers report a negative relationship (Eng \& Mak, 2003; Gul \& Leung, 2004; Muslu, 2005), while other researchers did not find any relationship (Haniffa \& Cooke, 2002; Ghazali \& Weetman, 2006). Accordingly, the first research hypothesis can be stated as follows:

H1: There is no relationship between BOD independence and the level of compliance with the IFRSs disclosure requirements.

\section{Board Leadership}

Board leadership is a governance mechanism that concerns with whether the chief executive officer (CEO) is also the Chair of the board of directors. The results of prior research investigated the association between board leadership and levels of financial disclosure are mixed. Some studies show that role duality is significantly associated with a lower level of financial disclosure (e.g., Haniffa \& Cooke, 2002; Gul \& Leung, 2004; Arcay \& Vazquez, 2005; Abdelsalam \& Elamasry, 2008) while Ghazali \& Weetman (2006) report an insignificant relationship. On the other hand, some empirical research show that there is no association between role duality and financial disclosure or reporting quality (Cheng \& Courtenay, 2006; Ghazali \& Weetman, 2006) and one study (Felo, 2009) reports a positive relationship between role duality and financial disclosure practices. The contradictory nature of these results and the non availability of a study that investigates the association between board leadership and levels of compliance with mandatory IFRSs disclosure requirements in the Jordanian context, make it difficult to predict the type of the relationship between board leadership and levels of compliance with IFRSs in Jordan. Accordingly, the second research hypothesis can be stated as follows:

H2: There are no statistically significant differences in the levels of compliance with the IFRSS disclosure requirements between companies that separate the positions of the CEO and the Chair and those that do not.

\section{Board Size}

Board size is one of the corporate governance mechanisms that help in aligning management and shareholder interests (Arcay \& Vazquez, 2005; Abdelsalam \& Street, 2007). Good governance practices recommend limitations to the size of the BOD (Arcay \& Vazquez, 2005), but there is no general consensus on the optimum. Findings from previous research into the association between board size and levels of financial disclosure are mixed. Some researchers report a positive relationship (Barako et al., 2006; Ezat \& El-Masry, 2008; Al-Akra et al., 2010a). However, others find no association (Arcay \& Vazquez, 2005; Abed et al., 2011). The contradictory nature of these results and the availability of only one study that investigates such association in the Jordanian context (Al-Akra et al., 2010a), make it difficult to predict the type of the relationship between board size and levels of compliance with IFRSs in Jordan . Accordingly, the third research hypothesis can be stated as follows:

H3: There is no significant statistical relationship between BOD size and the level of compliance with the IFRSS disclosure requirements. 


\subsection{Ownership Structure}

Ownership structure concerns with the identities and size of ownership of stockholders (Denis \& McConnell, 2003). The ownership structure of a firm may be a possible determinant of its disclosure practices (Eng \& Mak, 2003; Arcay \& Vazquez, 2005). High levels of concentration of capital may be accompanied by the owner's considerable involvement in the firm's management, which in turn may lead to unrestricted access to information, thus may limit the demand hence the supply for company information and vice versa (Haniffa \& Cooke, 2002; Arcay \& Vazquez, 2005; Ezat \& El-Masry, 2008). On the other hand, when share ownership is widely held, the potential for conflicts of interests between the principal and the agent is greater than in closely held companies. As a result, disclosure is likely to be greater in widely held companies to enable the principal to effectively monitor whether his/her economic interests are optimised and whether the agent acts in the best interests of the principal as an owner of the firm ( Chau \& Gray, 2002).

Based on the review of the patterns of ownership structure in the scrutinised companies and the availability of ownership structure related data for these companies, this study examines the influence of ownership structure on the levels of compliance with the IFRSs in the Jordanian context using four distinct measures; government ownership (defined as the percentage of company shares owned by the government), management ownership (defined as the percentage of company shares owned by company management), private ownership (defined as the percentage of company shares owned by private shareholders) and public ownership (defined as the percentage of company shares owned by the free float that is less than $5 \%$ ).

\subsection{Government ownership}

The results of prior studies that examined the association between government ownership and levels of financial disclosure are mixed. Previous research results concerning the association between government ownership and levels of financial disclosure are mixed. For instance, Eng and Mak (2003) report a positive relationship while Al-Razeen (1999) and Naser et al. (2006) report a negative one and Ghazali and Weetman (2006) find a negative, but insignificant relationship. On the level of scrutinised stock exchange, the results of all studies that investigate the association between government ownership and the extent of corporate disclosure do not support the existence of any association (Naser, 1998; Naser et al., 2002; Al-Akra et al., 2010a). Accordingly, research hypothesis (4a) can be stated as follows:

H4a: There is no significant statistical relationship between government ownership ratio and the level of compliance with the IFRSs disclosure requirements.

\subsection{Management Ownership}

To the best of the researcher's knowledge, this study is the first to investigate the association between management ownership ratio and level of compliance with IFRSs disclosure requirements in the Jordanian context. The results of the majority of prior studies that examined the association between management ownership and levels of financial disclosure show a negative association (e.g., Eng \& Mak, 2003; Arcay \& Vazquez, 2005; Ghazali \& Weetman, 2006; Abdelsalam \& El-Masry, 2008). Thus, the effect of management ownership on levels of compliance with the IFRSs is expected to be substitutive. Accordingly, research hypothesis (4b) can be stated as follows:

H4b: There is a significant negative statistical relationship between management ownership ratio and level of compliance with the IFRSs disclosure requirements.

\subsection{Private Ownership}

Similar to government ownership, there is no consensus among prior researchers regarding the influence of private ownership on the levels of compliance with financial disclosure requirements. Some researchers report that private ownership may be a complementary (Haniffa \& Cooke, 2002). On the contrary, some researchers report that concentrated ownership and financial disclosure are substitutes (Naser et al., 2006) while others report no association between the dominance of private ownership and levels of financial disclosure (Depoers, 2000). On the level of scrutinised stock exchange, this issue has been examined by Suwaidan (1997), Omar (2007) and Al-Akra et al. $(2010 \mathrm{a}, \mathrm{b})$ and all report non existence of any association. Accordingly, research hypothesis $(4 \mathrm{c})$ can be stated as follows: 
H4c: There is no statistically significant relationship between private ownership ratio and level of compliance with IFRSs disclosure requirements.

\subsection{Public Ownership}

The results of most prior studies show a positive association between public ownership and levels of financial disclosure (e.g., Haniffa \& Cooke, 2002; Al-Htaybat, 2005; Arcay \& Vazquez, 2005). However, Al-Akra et al. (2010b) results support the existence of a significant negative association and Naser et al. (2002) and Al-Akra et al. (2010a) findings do not support the existence of any association between public ownership ratio and the levels of compliance with IFRSs. Accordingly, research hypothesis $4 \mathrm{~d}$ can be stated as follows:

H4d: There is no significant statistical relationship between the public ownership ratio and level of compliance with IFRSs disclosure requirements.

\subsection{Control Variables}

Based on the findings of prior researchers (Eng \& Mak, 2003; Akhtaruddin, 2005; Aksu \& Kosedag, 2006 and Naser et al., 2006) firm size is included as a control variable and a positive association between firm size and levels of compliance with the IFRSs disclosure requirements is anticipated.

Evidence relating to the association between firm profitability and levels of financial disclosure is mixed. Some studies report a positive association between these variables (Akhtaruddin, 2005; Aksu \& Kosedag, 2006), while others report a significant negative association between them (Belkaoui \& Kahl, 1978; Wallace \& Naser, 1995). Consequently, the direction of the relationship between profitability and compliance with the IFRSs is unpredictable.

Evidence from prior research on the association between firm liquidity and levels of financial disclosure is mixed. Belkaoui and Kahl (1978) report a positive relationship. In contrast, Naser et al. (2002) find a negative relationship. Consequently, liquidity is used in this study as a control variable, recognising that the direction of the relationship between company liquidity and compliance levels is unpredictable.

Evidence regarding the association between gearing and level of financial disclosure is mixed. Some studies report a positive relationship (Naser, 1998; Naser et al., 2002; Barako et al., 2006), whilst others find a negative relationship (Zarzeski, 1996; Eng \& Mak, 2003). Consequently, gearing is employed in this study as a control variable, recognising that the direction of the relationship between the two variables is unpredictable. Based on the evidence provided by prior research that the type of business activity influences its disclosure practices (Haniffa \& Cooke, 2002), type of business activity will be employed in this study as a control variable. Based on the evidence provided by prior research that there is a relationship between the type of auditor and levels of company disclosure (Samaha \& Stapleton, 2009), type of auditor will be employed in this study as a control variable and it is expected that auditing by a big 4 audit firm has a positive impact on the levels of compliance with the IFRSs.

\section{Methodology}

\subsection{Sample Selection}

The annual reports of 2007 for the entire population of non-financial companies listed on the ASE (166 companies) formed the study population. Financial institutions such as banks and insurance companies were excluded because their reports are not comparable with those of non-financial companies as they are subject to other disclosure requirements. After applying the following criteria, the final sample contained 75 companies due to the absence of the first criterion:

The company should have a complete annual report for the year ended 31 December, 2007.

There should be information related to corporate governance structure within the company for the year 2007 .

\subsection{Disclosure Checklist}

To meet the purpose of this study the researcher uses a self-constructed disclosure checklist based on the IFRSs required to be followed by the IASB in preparing the financial statements for the fiscal year beginning January 2007 and which are mandated in the Jordanian context. The disclosure index employed in this study includes 275 IFRSs 
based items $\mathrm{s}^{\mathrm{b}}$. The disclosure index for each company was calculated as the ratio of the total actual score awarded to the maximum possible score of relevant items applicable for that company.

The calculation of the disclosure index (dependent variable) for each company under this approach is as follows:

$$
D I=A D S / M D
$$

Where:

DI refers to the disclosure index $(0 \leqslant \mathrm{DI} \leqslant 1)$.

ADS refers to the aggregate disclosure score for a particular company.

MD refers to the maximum score possible for that company.

\section{Data Collection and Regression Model}

The data on the chosen independent variables (see below) were obtained from Zawya data base. The following multiple regression model is proposed:

$Y j=\beta 0+\beta 1$ board independencej $+\beta 2$ board leadershipj $+\beta 3$ board sizej $+\beta 4$ government ownership ratioj + $\beta 5$ management ownership ratioj $+\beta 6$ private ownership ratioj $+\beta 7$ public ownership ratioj $+\beta 8$ total assetsj $+\beta 9$ return on assetsj $+\beta 10$ debt to equityj $+\beta 1$ 1 quick ratioj $+\beta 12$ type of business activityj $+\beta 13$ type of audit firm $j+\varepsilon j$

Where:

$\mathrm{Yj}=$ Disclosure index for companies $(\mathrm{j}=1, \ldots, 75)$ which denotes the dependent variable.

$\beta 0=$ The intercept.

$\varepsilon j=$ Error term.

The independent variables consist of seven test variables (board independence, board leadership, board size, government ownership ratio, management ownership ratio, private ownership ratio and public ownership ratio) and six control variables (firm size [proxied by total assets], profitability [proxied by return on assets], gearing [proxied by debt to equity], liquidity [proxied by quick ratio], type of business activity, and type of audit firm). Due to the nonnormality of distribution of dependent and independent variables, it was decided to use non-parametric tests and to run the regression analysis using normal scores as transforming data is a recommended approach in order to modify their distribution to look more normal (Field, 2005).

\section{Results and Analysis}

Descriptive Statistics

Descriptive Statistics for the level of Compliance with Mandatory IFRSS

The results of the analysis of the 75 annual reports of companies listed on the ASE are demonstrated in table 1.

Table 1. Descriptive Statistics of the level of Compliance with Mandatory IFRSs by Companies Listed on the ASE.

\begin{tabular}{lllll}
\hline Min. $\%$ & Max. $\%$ & Mean $\%$ & Std. Deviation & Percentage of companies above $50 \%$ \\
\hline 56 & 88 & 76 & 0.07 & $100 \%$ \\
\hline
\end{tabular}

Table 1 shows that the average level of compliance with the IFRSs disclosure requirements by non-financial companies listed on the ASE is $76 \%$. The minimum level of compliance was $56 \%$ and the maximum level was $88 \%$ implying that none of the companies listed on the ASE achieved full compliance with mandatory IFRSs disclosure requirements. Hence, de facto compliance with mandatory IFRSs disclosure requirements in the Jordanian context is

\footnotetext{
${ }^{b}$ The disclosure index employed in this study is not presented here to save space but available from author upon request.

${ }^{c}$ The result of tests of normality is not presented here to save space but available from author upon request.
} 
problematic. Comparing the findings of this study with those of the most recent study investigating compliance with IFRSs disclosure requirements within the Jordanian context (Al-Akra et al., 2010a), reveals a relative similarity in the minimum (58\% compared to $56 \%$ in this study), maximum ( $90 \%$ compared to $88 \%$ in this study) and the average levels of compliance with IFRSs disclosure requirements (79\% compared to $76 \%$ in this study). On the other hand, the non-increase in the average compliance levels reported in either Al-Akra et al. (2010a) or this study, compared to Omar (2007) can be partially attributed to the researcher's proposition that, certain barriers to full compliance still remain in the Jordanian context. Essentially, these relate to the dominance of secretive culture and low demand for improved disclosures. Additionally, some technical barriers prevail relating to the qualification and competency of accounting practitioners in Jordan and the JSC monitoring staff, non-existence of an official Arabic translation of IFRSs in Jordan, and to the weak enforcement of IFRSs disclosure requirements by the JSC.

\section{Descriptive Statistics for Independent Variables}

Table 2 shows that in Jordan board independence ranges from $0 \%$ to $86 \%$ with an average of $40 \%$. This implies that board independence is highly recognised in some Jordanian companies. However, this is only one face of the coin, the most important is the impact of this recommended mechanism on disclosure practices by listed companies on scrutinised stock exchange.

Table 2. Summary of Descriptive Statistics for Independent Variables.

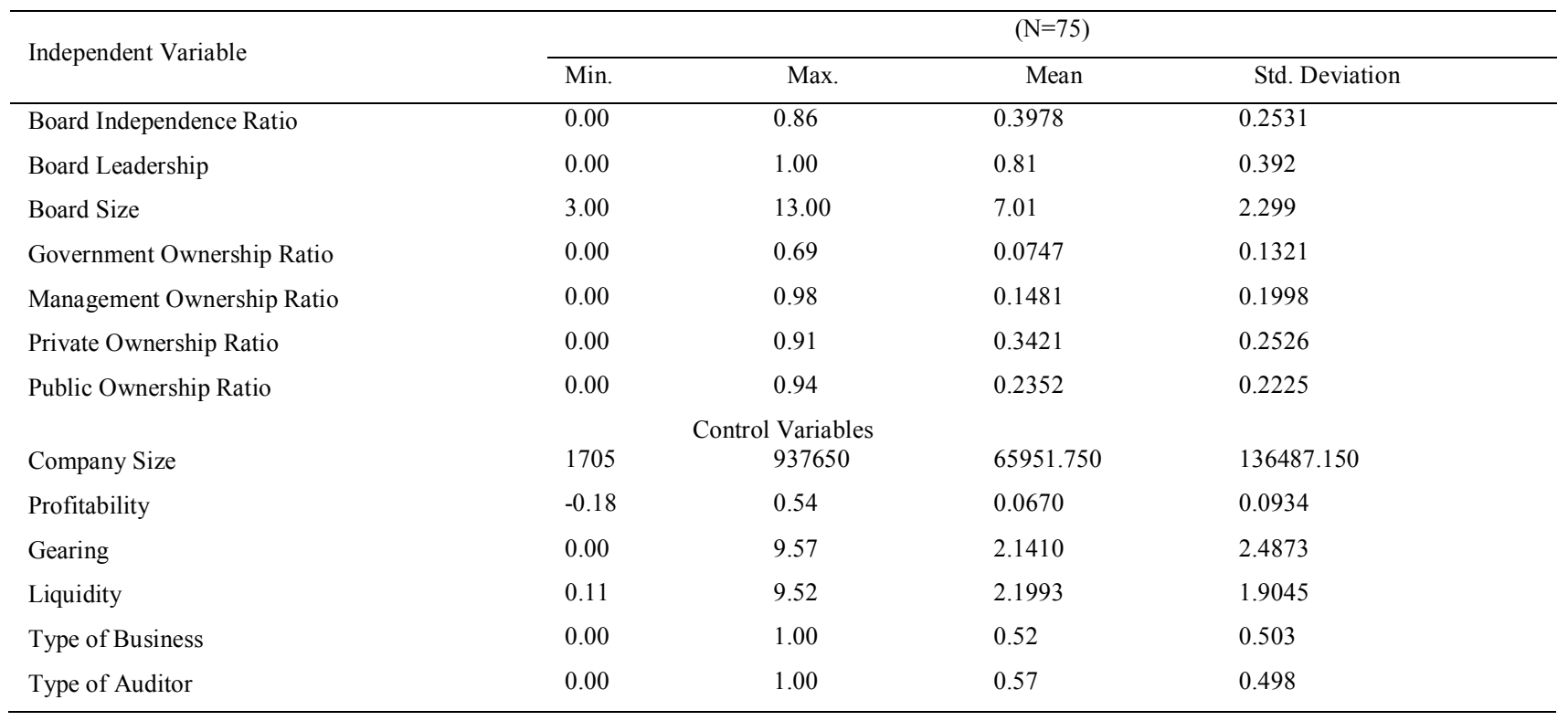

In respect of board leadership, the CEO and the Chair positions are held by two different persons in the majority of companies listed on the ASE (81\%). For board size, it ranges from 3 to 13 members, with an average board size of 7 members. With respect to government ownership ratio, this ranges from $0 \%$ to $69 \%$ with an average of $7 \%$. In terms of the management ownership ratio, this ranges from $0 \%$ to $98 \%$ with an average $15 \%$. The private ownership ratio is seen to range from $0 \%$ to $91 \%$ with an average of $34 \%$. Finally, with respect to public ownership, the ratio ranges from $0 \%$ to $94 \%$ with an average of $24 \%$.

The descriptive statistics of the control variables as in Table 2, show that the average firm size measured in terms of total assets is USD 65951.8 million. Profitability measured in terms of return on assets, indicates that the average profitability in companies listed on the ASE is $7 \%$. The gearing measured in terms of debt to equity, averages 2.14 . The average liquidity is very high (2.20). This implies the high ability of companies listed on the ASE to meet their short term obligations, which reflects the large margin of safety in companies listed on the ASE and their ability to continue as going concerns. This in turn has the potential to attract more direct foreign investments. Finally, the descriptive statistics of the categorical control variables as indicated in Table 2 show that $52 \%$ of the sample 
companies that are listed on the ASE are non-manufacturing. Also, it is recognised that $57 \%$ of the companies listed on the ASE are audited by non big 4 auditors.

Regression Analysis ${ }^{d}$

Stepwise regression on SPSS was performed, thus enabling the researcher to determine the individual contribution of each predictor in case the regression results proved that independent variables are related to the dependent variable (Field, 2005). This study uses the defaults of the SPSS Stepwise regression, which are 0.05 probability for entry and 0.10 probability for removal.

Table 3: Regression Results - (N=75)

\begin{tabular}{|c|c|c|c|c|c|c|c|}
\hline \multicolumn{8}{|l|}{ Model summary } \\
\hline & $\mathbf{R}$ & $\mathbf{R}^{2}$ & Adjusted $\mathbf{R}^{2}$ & \multicolumn{2}{|c|}{ Std. Error } & $\mathbf{F}$ & Sig. \\
\hline & .525 & .275 & .245 & \multicolumn{2}{|c|}{.832} & 8.988 & $.000 * * *$ \\
\hline \multicolumn{6}{|l|}{ Coefficients } & \multicolumn{2}{|c|}{ Collinearity Statistics } \\
\hline \multirow[t]{2}{*}{ Predictor Variable } & \multicolumn{2}{|c|}{$\begin{array}{c}\text { Unstandardised } \\
\text { Coefficients }\end{array}$} & $\begin{array}{c}\text { Standardised } \\
\text { Coefficients }\end{array}$ & $\mathbf{t}$ & Sig. & Tolerance & VIF \\
\hline & B & Std. Error & Beta & & & & \\
\hline (Constant) & .451 & .152 & & 2.967 & $.004 * * *$ & & \\
\hline Auditor Type & -.788 & .206 & -.405 & -3.779 & $.000 * * *$ & .889 & 1.125 \\
\hline Public Ownership & -.240 & .109 & -.230 & -2.194 & $.032 * *$ & .930 & 1.075 \\
\hline Firm Size & .226 & .103 & .226 & 2.188 & $.032 * *$ & .954 & 1.048 \\
\hline
\end{tabular}

**, *** Significant at the 0.05 and 0.01 Levels respectively

As demonstrated in Table 3 the adjusted $\mathrm{R} 2=.245$, implying that $24.5 \%$ of the variation in the total disclosure index (overall compliance with mandatory IFRSs disclosure requirements) in the Jordanian context is explained by the type of auditor, public ownership ratio and firm size. This result confirms and refines the results of the univariate analysis with respect to the existence of a significant relationship between the extent of compliance with IFRSs disclosure requirements, and auditor type and public ownership ratio. Additionally, the model reaches statistical significance with $\mathrm{F}=8.988$ and the significance $=.000(<0.01)$. The explanatory power of the total disclosure index model reported in this study exceeds that of Al-Akra et al. (2010a), who investigated the same issue in the Jordanian context in 1996 and 2004 respectively. The explanatory power of Al-Akra et al. (2010a) full model for 1996 was very low (6.3\%), however, it reached $14.7 \%$ in 2004.

The results reveal that, the influence of corporate governance best practice as recommended by the OECD corporate governance principles which are supported by the regulatory framework in Jordan on the levels of compliance with IFRSs is absent, possibly because of its novelty and the lack of awareness of the advantages of material compliance with its requirements in Jordan, meaning that as yet it is not part of the cultural values within the Jordanian context. Building on this, it can be argued that there are other factors mainly related to the secretive culture that is dominant in scrutinised MENA societies that possibly influence the levels of compliance with some IFRSs disclosure requirements in the Jordanian context. Table 3 indicates that, type of auditor with the highest Beta coefficient $(-0.405)$ is the best predictor in terms of the extent of compliance with the overall mandatory IFRSs disclosure requirements $(\mathrm{t}=-3.779$,

\footnotetext{
${ }^{\mathrm{d}}$ The results of the univariate analysis and the multicollinearity tests using Spearman Rank Correlation are not presented here to save space but available from author upon request.
} 
$\mathrm{P}=0.000)$ followed by public ownership ratio $(\mathrm{t}=-2.194, \mathrm{P}=0.032)$ and firm size $(\mathrm{t}=2.188, \mathrm{P}=0.032)$. From the information in Table 3 the total disclosure index model in the Jordanian context can be stated as:

Total Disclosure Index $=$ 0.451- 0.778 Auditor - 0.240 Public Ownership Ratio+ 0.226 Firm Size

In summary, the regression analysis reveals the type of auditor, public ownership ratio and firm size as the best predictors of the overall level of compliance with mandatory IFRSs disclosure requirements in the Jordanian context; at least among the variables included in the study. Companies listed on the ASE which are audited by big 4 audit firms comply better with the overall IFRSs mandatory disclosure requirements (the coefficient estimate is significant at 0.01). This result is reasonable as big 4 audit firms' staff are highly qualified and have better experience with IFRSs, and extensive training on any updates of these standards compared to auditors in local audit firms who may have limited experience and knowledge. This result supports the findings of many earlier studies (e.g., Wallace \& Naser, 1995; Inchausti, 1997; Samaha \& Stapleton, 2009). In addition, it supports those of Suwaidan (1997), Naser et al. (2002), Al-Shiab (2003), Omar (2007) and Al-Akra et al. (2010a) in the Jordanian context. However, given that none of the companies listed on the ASE which are audited by big 4 audit firms achieved full compliance with IFRSs disclosure requirements, although unqualified audit reports are issued, raises doubts regarding the quality of audit work performed by big 4 affiliates operating in Jordan. Such behaviour supports the continuity of the decoupling problem in Jordan as the case in Egypt (companies claim that financial statements are prepared in accordance with IFRSs while full compliance is absent). Such audit firms may not be strict as they may consider the companies to be operating in a developing market, and to require more time to adapt to the compliance culture in respect of IFRSs. Additionally, they may fear the prospect of losing the client should they issue qualified reports; and another possibility is that they may perceive their clients as the best of the worst and believe that issuing them with qualified reports will give an advantage to those companies with lower compliance levels but audited by non-big 4 audit firms. On the other hand the regression analysis reveals that public ownership ratio is the only corporate governance related variable that explains variations in the levels of compliance with mandatory IFRSs disclosure requirements in the Jordanian context. However there is a significant negative relationship between public ownership ratio and total disclosure index at the 0.05 level. In other words, companies with dominant public ownership complied less with the overall mandatory IFRSs disclosure requirements (i.e., they had the lowest total disclosure scores). This result supports that of Hossain et al. (1994). In addition, it supports that of Naser et al. (2002) and Al-Akra et al. (2010b) in the Jordanian context. However, it does not support those of Al-Htaybat (2005) in the Jordanian context. This result may be attributed to the lack of demand for more disclosure by public investors in Jordan. This confirms the proposition that, the majority of individual investors in Jordan are small unsophisticated investors, and their investment decisions in most of the cases are speculative and uninformed (Naser et al., 2002; Al-Akra et al., 2010a,b). Consequently, it can be said that as long as all parties involved in the financial reporting process are ignorant of the importance of transparency and de facto compliance with corporate governance and accounting international best practices, and as public investors are not aware of which disclosures are mandatory, they do not pressure the BOD or management to improve compliance with IFRSs. Hence, it is difficult to close the gap between de facto and de jure compliance with IFRSs disclosure requirements in Jordan. In addition, regression results indicate that large companies comply better with IFRSs disclosure requirements (the coefficient estimate is significant at 0.05 ). This confirms the findings of the majority of prior researchers (e.g., Eng and Mak, 2003; Akhtaruddin, 2005; Naser et al., 2006). It also supports the findings of Suwaidan (1997), Naser (1998), Naser et al. (2002), Omar (2007) and Al-Akra et al. (2010b) in the Jordanian context. This may be attributed to low costs of disclosing information in large companies. In addition, as large companies in most of the cases engage with big 4 audit firms, this will improve their compliance with mandatory disclosure requirements compared to small listed companies which engage with non-big 4 audit firms due to the high fees associated with engagement with big 4 ones. In addition, as they are the largest contributors in the Jordanian economy, they are keen about attracting foreign investors by achieving the highest levels of compliance with IFRSs disclosure requirements.

\section{Conclusion}

The disclosure indices of the 2007 annual reports of 75 non-financial companies listed on the ASE were tested for any association with corporate governance structures. The results indicated that the average level of compliance with IFRSs disclosure requirements was $76 \%$. However, the regression analysis reveals that public ownership ratio is the only corporate governance related variable that explains variations in the levels of compliance with mandatory IFRSs disclosure requirements in the Jordanian context. There is a significant negative relationship between public ownership ratio and total disclosure index at the .05 level. In other words, companies with dominant public ownership complied 
less with the overall mandatory IFRSs disclosure requirements (i.e., they had the lowest total disclosure scores). This result may be attributed to the lack of demand for more disclosure by public investors in the Jordanian context. This confirms the proposition that, the majority of individual investors in Jordan are small unsophisticated investors, and their investment decisions in most of the cases are speculative and uninformed. Reduced agency costs due to the lack of demand for more disclosure by public investors, accounts for this. Furthermore, Gray's (1988) accounting subcultural model and cost-benefit analysis, propose that, the secretive culture in the Jordanian context causes management to avoid the outflow of stock market price-sensitive information. In addition, secrecy is also associated with large power distance and the tendency to collectivism (Gray, 1988). Furthermore, the lack of listed companies' management and BOD awareness regarding the importance of compliance with IFRSs and of following corporate governance best practices to enhance transparency, the weak enforcement of laws and regulations, and the absence of materially independent board members with primary responsibility for protecting public shareholders' interests, cause non-compliance costs to be less than compliance costs. The fact that public shareholders in Jordan do not exercise their rights, adds to this situation, thereby management is not stimulated to improve compliance with IFRSs.

\section{References}

Abdelsalam, O., and El-Masry, A. 2008. The Impact of Board Independence and Ownership Structure on the Timeliness of Corporate Internet Reporting of Irish-listed Companies. Managerial Finance, 34(12), 907-918.

Abdelsalam, O.H., and Street, D.L. 2007. Corporate Governance and the Timeliness of Corporate Internet Reporting by UK Listed Companies. Journal of International Accounting, Auditing and Taxation, 16, 111-130.

Abed, S., Al-Okdeh, S, and Nimer, K. 2011. The Inclusion of Forecasts in the Narrative Sections of Annual Reports and their Association with Firm Characteristics: The Case of Jordan. International Business Research, 4(4), 264-271.

Akhtaruddin, M. 2005. Corporate Mandatory Disclosure Practices in Bangladesh. The International Journal of Accounting, 40, $399-422$.

Al-Akra, M., Ali, M. and Marashdeh, O. 2009. Development of Accounting Regulation in Jordan. The International Journal of Accounting, 44, 163-186.

Al-Akra, M., Eddie, I., and Ali, M.J. 2010a. The Influence of the Introduction of Accounting Disclosure Regulation on Mandatory Disclosure Compliance: Evidence from Jordan. The British Accounting Review, 42(3), 170-186.

Al-Akra, M., Eddie, I., and Ali, M.J. 2010b. The Association between Privatisation and Voluntary Disclosure: Evidence from Jordan. Accounting and Business Research, 40(1), 55-74.

Al-Omari, A. 2010. The Institutional Framework of Financial Reporting in Jordan. European Journal of Economics, Finance and Administrative Sciences, 22, 32-50.

Alanezi, F., and Albuloushi, S. 2011. Does The Existence of Voluntary Audit Committees Really Affect IFRS Required Disclosure? The Kuwaiti Evidence. International Journal of Disclosure and Governance, 8(2), 148-173.

Al-Htaybat, K. 2005. Financial Disclosure Practices: Theoretical Foundation and an Empirical Investigation on Jordanian Printed and Internet Formats. Ph.D. thesis, University of Southampton, UK.

Al-Razeen, A. 1999. The Quality of Annual Financial Reporting of Saudi Corporations: Users' Perceptions and Companies Practices. Ph.D. thesis, Cardiff University, UK.

Al-Shiab, M. 2003. Financial Consequences of IAS Adoption: The Case of Jordan. Ph.D. thesis, University of Newcastle UponTyne, UK.

Arcay, M.R.B., and Vazquez, M.F.M. 2005. Corporate Characteristics, Governance Rules and the Extent of Voluntary Disclosure in Spain. Advances in Accounting, 21, 299-331.

Barako, D.G., Hancock, P., and Izan, H.Y. 2006. Factors Influencing Voluntary Corporate Disclosure by Kenyan Companies. Corporate Governance, 14(2), 107-125.

Belkaoui, A., and Kahl, A. 1978. Corporate Financial Disclosure in Canada. Research monograph of the Canadian Certified General Accountants Association. Vancouver.

Cadbury Committee Report. 1992. Report of the Cadbury Committee on the Financial Aspects of Corporate Governance. Tech. 
rept. Cadbury Committee, Gee. London.

Chau, G.K., and Gray, S.J. 2002. Ownership Structure and Corporate Voluntary Disclosure in Hong Kong and Singapore. The International Journal of Accounting, 37, 247-265.

Chen, C.J.P. and Jaggi, B. 2000. Association Between Independent Non-executive Directors, Family Control and Financial Disclosures in Hong Kong. Journal of Accounting and Public Policy, 19 (4), 285-310.

Denis, Diane, and McConnell, John. 2003. International Corporate Governance. Working paper. European Corporate Gov. Institute.

Depoers, F. 2000. A Cost-Benefit Study of Voluntary Disclosure: Some Empirical Evidence from French Listed Companies. The European Accounting Review, 9(2), 245-263.

Eng, L.L., and Mak, Y.T. 2003. Corporate Governance and Voluntary Disclosure. Journal of Accounting and Public Policy, 22(4), $325-345$.

Ezat, A., and El-Masry, A. 2008. The Impact of Corporate Governance on the Timeliness of Corporate Internet Reporting by Egyptian Listed Companies. Managerial Finance, 34(12), 848-867.

Felo, A.J. (2009).Voluntary Disclosure Transparency, Board Independence and Expertise, and CEO Duality. Working Paper. Available: http:// ssrn.com/abstract=1373942. Accessed: 15/2/2010.

Field, A. 2005. Discovering Statistics Using SPSS. 2 edn. London: Sage Publications.

Ghazali, N.A.M., and Weetman, P. 2006. Perpetuating Traditional Influences: Voluntary Disclosure in Malaysia Following the Economic Crisis. Journal of International Accounting, Auditing and Taxation, 15, 226-248.

Gul, F.A., and Leung, S. 2004. Board Leadership, Outside Directors Expertise and Voluntary Corporate Disclosures. Journal of Accounting and Public Policy, 23, 351-379.

Haniffa, R.M., and Cooke, T.E. 2002. Culture, Corporate Governance and Disclosure in Malaysian Corporations. Abacus, 38(3), $317-349$.

Mallin, C.A. 2009. Corporate Governance. 3 edn. New York: Oxford University Press.

Naser, K. 1998. Comprehensiveness of Disclosure of Non-Financial Companies Listed on the Amman Financial Market. International Journal of Commerce and Management, 8(1), 88-119.

Naser, K., Al-Khatib, K., and Karbhari, Y. 2002. Empirical Evidence on the Depth of Corporate Information Disclosure in Developing Countries: The Case of Jordan. International Journal of Commerce \& Management, 12, 122-155.

Naser, K., Al-Hussaini, A., Al-Kwari, D., and Nuseibeh, R. 2006. Determinants of Extent of Corporate Social Disclosure in Developing Countries: The Case of Qatar. Advances in International Accounting, 19(1-23).

OECD. 2004. Organization for Economic Cooperation and Development. Paris: OECD Principles of Corporate Governance, $O E C D$ Publications.

Omar, B.F.A. 2007. Exploring the Aggregate, Mandatory and Voluntary Financial Disclosure Behaviour

Under a New Regulatory Environment: The Case of Jordan. Ph.D. thesis, The University of Hull, UK.

Samaha, K., and Dahawy, K. 2010. Factors Influencing Corporate Disclosure Transparency in the Active Share Trading Firms: An Explanatory Study. Research in Accounting in Emerging Economies, 10, 87-118.

Samaha, K., and Dahawy, K. 2011. An Empirical Analysis of Corporate Governance Structures and Voluntary Corporate Disclosure in Volatile Capital Markets: The Egyptian Experience. International Journal of Accounting, Auditing and Performance Evaluation, 7(1/2), 61-93.

Samaha, K., and Stapleton, P. 2009. Firm-specific Determinants of the Extent of Compliance with Internatonal Accounting Standards in the Corporate Annual Reports of Companies Listed on the Egyptian

Stock Exchange: A Positive Accounting Approach. Afro-Asian Journal of Finance and Accounting, 1(3), 266-294.

Shanikat, M. \& Abbadi, S. 2011. Assessment of Corporate Governance in Jordan: An Empirical Study, Australasian Accounting Business and Finance Journal, 5(3), 93-106. 
Suwaidan, M.S. 1997. Voluntary Disclosure of Accounting Information: the Case of Jordan. Ph.D. thesis, University of Aberdeen, UK.

Tricker, Bob. 2009. Corporate Governance: Principles, Policies and Practices. New York: Oxford University Press.

Wallace, R.S.O., and Naser, K. 1995. Firm-Specific Determinants of the Comprehensiveness of Mandatory Disclosure in the Corporate Annual Reports of Firms Listed in the Stock Exchange of Hong Kong. Journal of Accounting and Public Policy, 14, 311-368.

Zarzeski, M.T. 1996. Spontaneous Harmonization Effects of Culture and Market Forces on Accounting Disclosure Practices. Accounting Horizons, 10(1), 18-37. 